\title{
The Effect of Zinc Oxide Nanoparticles for Enhancing Rice (Oryza sativa L.) Yield and Quality
}

\author{
Haipeng Zhang ${ }^{\dagger}$, Rui Wang ${ }^{\dagger}$, Zhiqing Chen, Peiyuan Cui, Hao Lu, Yanju Yang * and Hongcheng Zhang * \\ Jiangsu Co-Innovation Center for Modern Production Technology of Grain Crops, Jiangsu Key Laboratory of \\ Crop Cultivation and Physiology, Yangzhou University, Yangzhou 225009, China; hpzhang@yzu.edu.cn (H.Z.); \\ chinaniubi0@gmail.com (R.W.); MX120190550@163.com (Z.C.); pycui@yzu.edu.cn (P.C.); \\ 007559@yzu.edu.cn (H.L.) \\ * Correspondence: yangyanju@yzu.edu.cn (Y.Y.); hczhang@yzu.edu.cn (H.Z.) \\ + Both authors contributed equally to this work.
}

Citation: Zhang, H.; Wang, R.; Chen, Z.; Cui, P.; Lu, H.; Yang, Y.; Zhang, H. The Effect of Zinc Oxide

Nanoparticles for Enhancing Rice (Oryza sativa L.) Yield and Quality. Agriculture 2021, 11, 1247. https:// doi.org/10.3390/agriculture11121247

Academic Editors: Othmane Merah, Purushothaman

Chirakkuzhyil Abhilash, Magdi

T. Abdelhamid, Hailin Zhang and Bachar Zebib

Received: 7 November 2021

Accepted: 8 December 2021

Published: 9 December 2021

Publisher's Note: MDPI stays neutral with regard to jurisdictional claims in published maps and institutional affiliations.

Copyright: (c) 2021 by the authors. Licensee MDPI, Basel, Switzerland. This article is an open access article distributed under the terms and conditions of the Creative Commons Attribution (CC BY) license (https:/ / creativecommons.org/licenses/by/ $4.0 /)$.
Abstract: Zinc oxide nanoparticles (ZnO NPs) have been applied widely in agriculture, and many studies were conducted to evaluate the effect of ZnO NPs on plant growth. So far, few studies have been investigated with regard to the potential effect of ZnO NPs on cereal yield formation or $\mathrm{Zn}$ content in grains. Herein, we used a pot experiment, which was conducted involving five dosages of $\mathrm{Zn}\left(0.3,0.6,1.2,2.4\right.$, and $\left.4.8 \mathrm{~g} \mathrm{Zn} \mathrm{pot}^{-1}\right)$, to evaluate the impacts which $\mathrm{ZnO}$ NPs made in rice yield, dry matter accumulation, rice quality and grain Zn contents. The results demonstrated that ZnO NPs increased the production of grain, dry matter accumulation and particulate $Z n$ content. Compared with control treatment, $\mathrm{ZnO}$ NPs application presented higher rice yield with more panicle number (4.83-13.14\%), spikelets per panicle (4.81-10.69\%), 1000-grain weight (3.82-6.62\%) and filled grain rate $(0.28-2.36 \%)$. Additionally, the dry jointing, heading and mature periods, LAI, SPAD values, and photosynthetic potentials of ZnO NPs were all significantly higher relative to treatment without $\mathrm{ZnO}$ NPs. The more photosynthetic substances and higher dry matter accumulated in the whole rice growing stage resulted in higher rice grain yield. Furthermore, ZnO NPs increased brown rice rate, milled rice rate, head rice rate, chalkiness size, chalkiness grain rate, chalkiness degree, amylose content and protein content, improving rice processing and appearance qualities. For the Zn nutrition in rice grain, $\mathrm{ZnO}$ NPs application significantly increased the $\mathrm{Zn}$ content of edible polished rice and promoted the relocation of $\mathrm{Zn}$ from the aleurone layer. This study effectively demonstrated that $\mathrm{ZnO}$ NPs could be a potential high-performed fertiliser for enhancing rice yield and quality.

Keywords: Zinc oxide nanoparticles; yield formation; rice quality; photosynthetic potential

\section{Introduction}

As one of the crucial aspects of plant growth or development, Zinc ( $\mathrm{Zn})$ is a significant element found in plants. It promotes photosynthesis, carbohydrate and phosphorus metabolism of plants and promotes the development of grains [1]. $\mathrm{Zn}$ is also closely related to human health. Zn deficiency will slow the growth and development of the human body and weaken immunity [2-6]. As one of the most vital staple grains for the global population, rice is an essential source of energy, vitamins, mineral ingredients, and rare amino acids for people consuming rice as the staple food in daily life $[7,8]$. However, the $\mathrm{Zn}$ content of rice is exceedingly low, at approximately $20 \mathrm{mg} \mathrm{kg} \mathrm{g}^{-1}$, and could not supply the human body's demands that require $40-50 \mathrm{mg} \mathrm{kg}^{-1}[9,10]$. In recent decades, many studies have investigated how to reverse $\mathrm{Zn}$ deficiency in rice. For example, breeding, genetic modification, and agricultural practices in bio-fortification are all considered strategies [11-13].

$\mathrm{Zn}$ fertiliser application to leaves and soil can increase the absorption and transformation of $\mathrm{Zn}$ to the edible segments of plants. Foliar fertilisation is an effective and safe approach to enrich $\mathrm{Zn}$ levels in crops. Leaf-applied substances can penetrate the cuticle 
or the stomatal pathway to enter the leaf. Fang et al. reported that zinc foliar fertiliser application at the flowering stage could highly increase the $\mathrm{Zn}$ content of the rice [14]. However, the sustainability of $\mathrm{Zn}$ ions adhering to the surface of rice leaves is too challenging, and sprayed zinc solutions easily drip from leaves or are leached by the rain, which affects leaf absorption of Zn. Notably, Zn fertiliser application to the soil increases the Zn content of grains while also increasing grains' yield $[15,16]$. Many research reports on $\mathrm{Zn}$ fortification of rice show that the amount of $\mathrm{Zn}$ fertiliser facilitates rice growth, and an appropriate amount of $\mathrm{Zn}$ increases rice yield [17,18]. Unfortunately, the iron and aluminium oxides, clay minerals, and humus in the soil can adsorb and fix $\mathrm{Zn}$ ions, reducing $\mathrm{Zn}$ fertiliser's effectiveness in the soil. Moreover, $\mathrm{Zn}$ fertiliser not absorbed will accumulate in the agricultural soil and could have adverse impacts on the agricultural ecosystem [19]. Therefore, it is necessary to search for a new fertiliser containing $\mathrm{Zn}$, which should have high positive performance and low negative environmental impacts and could be substituted for conventional $\mathrm{Zn}$ fertilisers.

Studies based on the implications of nanotechnology in agricultural areas have been exponentially growing over the past decades $[20,21]$. Recently, researchers have evaluated that nano-zinc can be absorbed and utilised by crops and increase grain yields and $\mathrm{Zn}$ content $[22,23]$. For instance, Dimpkpa et al. reported that under low NPK fertilisation circumstances, Zn oxide nanoparticles (ZnO NPs) would increase growth, nutrient absorption and sorghum crops $\mathrm{Zn}$ content [24]. The application of nano-zinc fertiliser can increase the $\mathrm{Zn}$ content of grains and promote root development, improving rice growth $[18,25]$. The positive impacts of $\mathrm{ZnO}$ NPs on Cd levels alleviation in several plant species have also been reported [11-13]. ZnO NPs s are non-saturable and can be integrated with other atoms and stabilised, exhibiting high chemical activity. As the particle size decreases, the surface area, surface energy and surface binding energy of ZnO NPs particles increase rapidly [26]. Therefore, compared with traditional fertilisers, nano-zinc fertilisers are less affected by soil texture, structure, and colloidal content, for example, and are easily absorbed and utilised by plants. There are many positive implications of $\mathrm{ZnO}$ NPs for increasing the $\mathrm{Zn}$ content of grains, particularly cereal grains. Additionally, most ZnO NPs are combined with traditional fertilisers to develop new fertilisers or are used as seed dressing agents [27]. However, few studies have considered the influences of applied ZnO NPs on rice yield formation or $\mathrm{Zn}$ content in grains.

This study utilised pot experiments to study the implications of ZnO NPs fertiliser applied to the soil on grain yield, components, biomass, rice quality and $\mathrm{Zn}$ content. The purposes of this study were: (1) the investigations of the effects of applied ZnO NPs on rice yield and growth performance, and (2) to evaluate the influences of $\mathrm{ZnO} N P s$ application rates on the $\mathrm{Zn}$ content of the grains and quality of the rice. It is anticipated that the research results will provide significant resources for safely applying ZnO NPs, which is a new fertiliser in the rice production process.

\section{Materials and Methods}

\subsection{Zn Origination and Characteristic Traits}

Researchers purchased ZnO NPs from Shanghai Chaowei Nano Technology Co., Ltd., and $\mathrm{ZnSO}_{4} \cdot 7 \mathrm{H}_{2} \mathrm{O}$ was purchased from Aladdin Chemical Co., Ltd. Scanning electron microscopy (SEM) was used to confirm that ZnO NPs were spherical, with a particle size of $20-50 \mathrm{~nm}$ and a specific surface area of $133.6 \mathrm{~m}^{2} \mathrm{~g}^{-1}$.

\subsection{Experimental Location and Design Process}

In this study, a pot experiment was conducted in Yangzhou University, Yangzhou, Jiangsu Province, China, during the rice-growing seasons in 2020. Soil that was identified as sandy loam soil was collected from a nearby paddy field. The organic substance density was $12.6 \mathrm{~g} \mathrm{~kg}^{-1}$, and the total nitrogen $(\mathrm{N})$ content was $9.4 \mathrm{~g} \mathrm{~kg}^{-1}$. The available $\mathrm{N}$ was $73.3 \mathrm{mg} \mathrm{kg}^{-1}$. The available phosphorus (P) was $85.6 \mathrm{mg} \mathrm{kg}^{-1}$. The available potassium (K) was $103.1 \mathrm{mg} \mathrm{kg}^{-1}$, while available $\mathrm{Zn}$ contents of the $0-20 \mathrm{~cm}$ topsoil was $0.98 \mathrm{mg} \mathrm{kg}^{-1}$. 
During the pot experiments, the control was used as the treatments (no Zn fertiliser, CK), applied ZnO NPs of the basal stage with a content of 0.3 as T1, 0.6 as T2, 1.2 as T3, 2.4 as $\mathrm{T} 4$, and 4.8 as T5 $\mathrm{Zn} \mathrm{pot}{ }^{-1}$, respectively. According to the area of the pot, the amounts of $\mathrm{ZnO}$ NPs application in T1, T2, T3, T4, and T5 treatments are equivalent to 7.5, 15, 30, 60 and $120 \mathrm{~kg} \mathrm{hm}^{-2}$, respectively.

A total of 60 PVC pots (ten replicates for each of the six treatments) were used in this study. Both the length and height of the pot are $75 \mathrm{~cm}$, while the width of the pot is $50 \mathrm{~cm}$. The Oryza sativa L. cv. Nanjing 9108 was used in this study as the rice cultivar. On June 19 , the experiment used rice seedlings with a density of $25 \mathrm{~cm} \times 12.5 \mathrm{~cm}$, i.e., 16 holes per pot and four seedlings per hole and was transplanted. The $\mathrm{N}$ fertiliser (urea, $\mathrm{N}=46 \%$ ) in the experiment was $270 \mathrm{~kg} \mathrm{~N} \mathrm{hm}^{-2}$ and was applied with basal, tillering, and panicle fertilizer at a ratio of 3:3:4 at the relevant growth stage. The potash fertiliser (potassium chloride, $\mathrm{K}_{2} \mathrm{O}=60 \%$ ) was applied at $270 \mathrm{~kg} \mathrm{~K}_{2} \mathrm{O} \mathrm{hm}{ }^{-2}$, while the phosphate fertiliser (superphosphate, $\mathrm{P}_{2} \mathrm{O}_{5}=16 \%$ ) application-level was $\mathrm{P}_{2} \mathrm{O}_{5} \mathrm{~kg} \mathrm{~N} \mathrm{hm}^{-2}$. Moreover, the potash fertiliser was applied as $50 \%$ basal fertiliser $+50 \%$ panicle fertiliser. The phosphate fertiliser was applied entirely as basal fertiliser. The rice was harvested on 15 October 2020. According to what was observed on the field, the grain-filling period of rice was 46 days. The pots were arranged in a completely randomised design throughout the experiment.

\subsection{Measurements and Analysis}

\subsubsection{Dry Matter Accumulation and Leaf Area Index}

In stages of jointing (panicle initiation), heading and maturity, this research regarded plants from five prominent hills of each pot as samples to evaluate the mean amount of stems or tillers per pot. This study also used the length-width coefficient method to measure the leaf area during the jointing or heading stages. Each sample is then divided into four parts; green leaves, stems plus sheaths, and panicles would be put into kraft paper bags and placed in an oven. After drying at $105^{\circ} \mathrm{C}$ for $30 \mathrm{~min}$, samples were oven-dried at $72{ }^{\circ} \mathrm{C}$ in the bags and stopped when a constant weight had been obtained. The last step is to measure the dry matter weight of each part of the ground.

\subsubsection{SPAD Value and Photosynthesis Potential}

The SPAD values were determined using a chlorophyll meter (SPAD-502). The SPAD value presented in this paper was the average value of 10 leaf chlorophyll measurements.

The following equation was used for photosynthesis potential calculations:

$$
\text { Photosynthesis potential }\left(\mathrm{m}^{2} \mathrm{~m}^{-2} \mathrm{~d}\right)=\left[\left(\mathrm{L}_{1}+\mathrm{L}_{2}\right) \times\left(t_{1}-t_{2}\right)\right] / 2
$$

where $L_{1}$ and $L_{2}$ are the first and second measurements of leaf area indices $\left(\mathrm{m}^{2} \mathrm{~m}^{-2}\right)$.

\subsubsection{Grain Yield and Yield Components}

The number of panicles was measured separately from 20 hills, randomly selected from each treatment during the mature stage of the grain. Based on the average panicles for each plant, the rice panicles, which were contained in three plants, were assembled and then put in net bags to measure the grain number of each panicle, seed setting rate, and 1000-grain weight. At the mature period, the study continuously harvested 50 hills in each treatment. Simultaneously, this study used an LDS-1G grain moisture meter for three functions: calculating the grain moisture content, removing impurities, and converting the actual yield to $14.5 \%$ moisture content. When the rice reached maturity, three pots of rice plants were randomly chosen for every treatment to analyse the yield and yield components. The dry weight of these organs was measured by separating the rice plants from stems, leaves and ears, and panicles and then drying them at a regulated temperature of $80^{\circ} \mathrm{C}$. 


\subsubsection{Rice Quality}

The harvested rice plants from treatments were threshed, dried by air, and stored inside for 90 days. Firstly, air will select them, also by NP-450 winnowing machine [28]. After that, they were mixed with three other samples, each of which weighed $200 \mathrm{~g}$. Based on the NY/T83, the study measured brown rice rate, milled rice rate, head rice rate, chalkiness size, chalkiness grain rate, chalkiness degree, and amylose content. Protein levels were measured by using a FOSS Kjeldahl nitrogen analyser as well.

\subsubsection{Determination of Zn Content}

A huller hulled the unhusked rice. A grinder was used for crushing the brown rice and glume. For gaining milled rice, the brown rice should be polished. Firstly, those samples were thoroughly analysed with two elements which were $\mathrm{HNO}_{3}$ and $\mathrm{HClO}_{4}$. Secondly, an Inductively Coupled Plasma Optical Emission Spectrometer (ICP-OES) was used to measure the $\mathrm{Zn}$ content of the brown rice and glume. Briefly, the samples $(0.3 \mathrm{~g}$ per replication) were transferred to a digestion tank containing $5 \mathrm{~mL}$ nitric acid $(65 \%, v / v)$ for mineralization using a MARS6 high-throughput closed microwave digestion system. After the ashes were dissolved and filtered overnight, $2 \mathrm{~mL}$ of hydrogen peroxide $(30 \%, v / v)$ was added to each digestion tank. Then the final solution was transferred to a 50-mL flask and the volume was made up to $50 \mathrm{~mL}$ with deionized water.

\subsection{Data Analysis}

One-way analysis of variance (ANOVA) was applied using SPSS 20.0 to analyse the data. The LSD test was applied at a 0.05 probability level to establish the significance of discrepancy among each mean.

\section{Results}

\subsection{Rice Yield and Its Components}

The data in Table 1 depicts the influence of ZnO NPs on grain yield and yield parts of rice. The application of $\mathrm{ZnO}$ NPs significantly increased rice grain yield, and it increased at first but then decreased with the increasing ZnO NPs application. The increase following treatments of ZnO NPs was possibly correlated with the increased panicle amount (4.83$13.14 \%)$ in grain yield, spikelets per panicle (4.81-10.69\%), 1000-grain weight (3.82-6.62\%) and filled grain rate $(0.28-2.36 \%)$. Notably, with increasing levels of ZnO NPs applied, the variation of panicle number first increased and then decreased, and the highest panicle number was observed in the T4 group. The ANOVA results demonstrated no extreme differences in panicle number among the different $\mathrm{ZnO}$ NPs application amounts. The Spikelets per panicle, 1000-grain weight and filled grain rate under ZnO NPs treatments had no consistently significant changes.

Table 1. Rice yield and its components under different ZnO NPs application amounts.

\begin{tabular}{|c|c|c|c|c|c|}
\hline Treatments & $\begin{array}{c}\text { Panicle } \\
\left(\times 10^{6} \mathrm{hm}^{-2}\right)\end{array}$ & $\begin{array}{l}\text { Spikelets } \\
\text { Per Panicle }\end{array}$ & $\begin{array}{l}\text { 1000-Grain } \\
\text { Weight (g) }\end{array}$ & $\begin{array}{l}\text { Filled Grain Rate } \\
(\%)\end{array}$ & $\begin{array}{l}\text { Harvest Yield } \\
\quad\left(\mathrm{t} \mathrm{hm}^{-2}\right)\end{array}$ \\
\hline CK & $3.73 \pm 0.15^{b}$ & $108.09 \pm 1.39^{d}$ & $25.68 \pm 0.24^{\mathrm{c}}$ & $88.22 \pm 0.57^{\mathrm{d}}$ & $10.07 \pm 0.15^{c}$ \\
\hline $\mathrm{T} 1$ & $3.99 \pm 0.20^{\mathrm{a}, \mathrm{b}}$ & $113.29 \pm 1.14^{\mathrm{c}}$ & $26.67 \pm 0.08^{b}$ & $88.47 \pm 0.15^{\mathrm{d}}$ & $10.40 \pm 0.25^{b c}$ \\
\hline $\mathrm{T} 2$ & $4.03 \pm 0.15^{\mathrm{a}, \mathrm{b}}$ & $116.40 \pm 0.73^{b}$ & $27.38 \pm 0.02^{\mathrm{a}}$ & $89.30 \pm 0.17^{c}$ & $10.57 \pm 0.15^{\mathrm{a}, \mathrm{b}}$ \\
\hline $\mathrm{T} 3$ & $3.97 \pm 0.15^{\mathrm{a}, \mathrm{b}}$ & $119.64 \pm 0.80^{\mathrm{a}}$ & $27.13 \pm 0.02^{\mathrm{a}}$ & $89.61 \pm 0.11^{b, c}$ & $10.62 \pm 0.30^{\mathrm{a}, \mathrm{b}}$ \\
\hline $\mathrm{T} 4$ & $4.22 \pm 0.25^{\mathrm{a}}$ & $113.92 \pm 3.03 b, c$ & $27.26 \pm 0.14^{\mathrm{a}}$ & $90.30 \pm 0.07^{\mathrm{a}}$ & $10.83 \pm 0.33^{a}$ \\
\hline $\mathrm{T} 5$ & $3.91 \pm 0.16^{\mathrm{a}, \mathrm{b}}$ & $116.20 \pm 1.36^{b}$ & $26.68 \pm 0.23^{b}$ & $90.01 \pm 0.34^{\mathrm{a}, \mathrm{b}}$ & $10.55 \pm 0.21^{\mathrm{a}, \mathrm{b}}$ \\
\hline
\end{tabular}

Note: Values within the same column followed by different letters are significantly different at the 0.05 probability level. 


\subsection{Dry Matter Accumulation}

The accumulation of dry matter in rice is the key to the formation of grain yield. As shown in Table 2, the application of ZnO NPs significantly increased rice dry matter weight at the jointing, heading, and mature stages. Compared with CK treatment, the dry matter weights of ZnO NPs treatments were $12.93-19.53 \%$ higher at the jointing stage, $19.38-22.97 \%$ higher at the handling stage, and $9.88-16.98 \%$ higher at the maturity stage. No significant effects were detected on rice dry matter weight at all growth stages among the different $\mathrm{ZnO}$ NPs treatments. The higher growth rate of dry matter weight at the heading stage suggests that $\mathrm{ZnO}$ NPs played an integral role in the formation of rice yield at this period. This proposal was confirmed with dry matter accumulation and proportion in different growth stages of rice in Table 3. The most significant dry matter accumulation and proportion stage of rice was observed at the jointing-heading stage. The weight of dry matter in a certain period reflected the growth status of the ZnO NPs treatments during that period. The cumulative amount and proportion of dry matter during the period showed the growth rate and characteristics of the growth process of rice. Therefore, the higher dry matter accumulation in the jointing-heading stage would increase the final yield, consistent with the grain yield results. Moreover, rice dry matter cumulative amounts at the heading-maturity stages of T2, T3, T4, and T5 were higher than CK, suggesting that the $\mathrm{ZnO}$ NPs also improve the dry substances' accumulation in the latter growing stage of rice.

Table 2. Dry matter weight of rice under different ZnO NPs application amounts.

\begin{tabular}{ccccc}
\hline \multirow{2}{*}{ Treatments } & \multicolumn{3}{c}{ Dry Matter Weight $\mathbf{( t ~ h \mathbf { ~ } ^ { - 2 } )}$} & \multirow{2}{*}{ Harvest Index } \\
\cline { 2 - 4 } & Jointing & Heading & Maturity & \\
\hline CK & $3.79 \pm 0.25^{\mathrm{b}}$ & $10.58 \pm 1.11^{\mathrm{b}}$ & $16.90 \pm 1.08^{\mathrm{b}}$ & $0.37 \pm 0.08^{\mathrm{a}}$ \\
T1 & $4.32 \pm 0.40^{\mathrm{a}}$ & $12.63 \pm 1.41^{\mathrm{a}}$ & $18.57 \pm 1.25^{\mathrm{a}}$ & $0.36 \pm 0.05^{\mathrm{a}}$ \\
T2 & $4.30 \pm 0.38^{\mathrm{a}}$ & $12.74 \pm 0.80^{\mathrm{a}}$ & $19.37 \pm 1.16^{\mathrm{a}}$ & $0.35 \pm 0.09^{\mathrm{a}}$ \\
T3 & $4.28 \pm 0.27^{\mathrm{a}}$ & $12.87 \pm 1.85^{\mathrm{a}}$ & $19.66 \pm 1.50^{\mathrm{a}}$ & $0.35 \pm 0.04^{\mathrm{a}}$ \\
T4 & $4.53 \pm 0.37^{\mathrm{a}}$ & $13.00 \pm 1.55^{\mathrm{a}}$ & $19.77 \pm 1.56^{\mathrm{a}}$ & $0.35 \pm 0.09^{\mathrm{a}}$ \\
T5 & $4.45 \pm 0.52^{\mathrm{a}}$ & $13.01 \pm 0.95^{\mathrm{a}}$ & $19.73 \pm 1.22^{\mathrm{a}}$ & $0.35 \pm 0.08^{\mathrm{a}}$ \\
\hline
\end{tabular}

Note: Values within the same column followed by different letters are significantly different at the 0.05 probability level.

Table 3. Dry matter accumulation and proportion in different growth stages of rice under different ZnO NPs application amounts.

\begin{tabular}{|c|c|c|c|c|c|c|}
\hline \multirow[b]{2}{*}{ Treatments } & \multicolumn{2}{|c|}{ Sowing-Jointing } & \multicolumn{2}{|c|}{ Jointing-Heading } & \multicolumn{2}{|c|}{ Heading-Maturity } \\
\hline & $\begin{array}{l}\text { Accumulation } \\
\left(\mathrm{t} \mathrm{hm}^{-2}\right)\end{array}$ & $\begin{array}{c}\text { Ratio } \\
(\%)\end{array}$ & $\begin{array}{l}\text { Accumulation } \\
\left(\mathrm{t} \mathrm{hm}^{-2}\right)\end{array}$ & $\begin{array}{c}\text { Ratio } \\
(\%)\end{array}$ & $\begin{array}{l}\text { Accumulation } \\
\left(\mathrm{t} \mathrm{hm}^{-2}\right)\end{array}$ & $\begin{array}{c}\text { Ratio } \\
(\%)\end{array}$ \\
\hline CK & $3.79 \pm 0.25^{b}$ & $22.76 \pm 6.58^{a}$ & $6.79 \pm 0.78^{b}$ & $40.07 \pm 9.54^{a}$ & $6.32 \pm 1.28^{a}$ & $37.17 \pm 8.43^{a}$ \\
\hline $\mathrm{T} 1$ & $4.32 \pm 0.40^{\mathrm{a}}$ & $23.24 \pm 0.72^{\mathrm{a}}$ & $8.31 \pm 1.41^{\mathrm{a}}$ & $44.86 \pm 6.48^{\mathrm{a}}$ & $5.94 \pm 1.25^{\mathrm{a}}$ & $31.90 \pm 6.81^{a}$ \\
\hline $\mathrm{T} 2$ & $4.30 \pm 0.38^{a}$ & $22.30 \pm 2.10^{a}$ & $8.44 \pm 0.80^{a}$ & $43.71 \pm 2.96^{\mathrm{a}}$ & $6.63 \pm 1.16^{\mathrm{a}}$ & $33.99 \pm 3.46^{\mathrm{a}}$ \\
\hline $\mathrm{T} 3$ & $4.28 \pm 0.27^{\mathrm{a}}$ & $21.93 \pm 3.00^{\mathrm{a}}$ & $8.59 \pm 1.85^{\mathrm{a}}$ & $43.30 \pm 7.28^{a}$ & $6.79 \pm 1.50^{\mathrm{a}}$ & $34.77 \pm 4.35^{\mathrm{a}}$ \\
\hline $\mathrm{T} 4$ & $4.53 \pm 0.37^{a}$ & $23.10 \pm 3.83^{a}$ & $8.47 \pm 1.55^{\mathrm{a}}$ & $42.92 \pm 7.21^{\mathrm{a}}$ & $6.77 \pm 1.56^{\mathrm{a}}$ & $33.99 \pm 9.25^{\mathrm{a}}$ \\
\hline $\mathrm{T} 5$ & $4.45 \pm 0.52^{\mathrm{a}}$ & $22.51 \pm 1.66^{\mathrm{a}}$ & $8.56 \pm 0.95^{\mathrm{a}}$ & $43.51 \pm 6.22^{a}$ & $6.72 \pm 1.22^{\mathrm{a}}$ & $33.98 \pm 4.59^{\mathrm{a}}$ \\
\hline
\end{tabular}

Note: Values within the same column followed by different letters are significantly different at the 0.05 probability level.

\subsection{Leaf Area Index, Decreasing Rate of Leaf Area at the Grain-Filling Stage}

Leaf area index (LAI) can directly affect the interception and utilisation of light energy through plants, affecting rice plants' growth and development in turn. As shown in Table 4, the LAI of CK treatment was lower than those of ZnO NPs treatments at the jointing and maturity stages. At the heading stage, LAI of low $\mathrm{ZnO}$ NPs application amount treatments (T1 and T2) were slightly lower than CK treatment without marked differences. The LAI of $\mathrm{ZnO}$ NPs treatments increased with the increase of ZnO NPs dosage, indicating that the $\mathrm{ZnO}$ NPs application greatly affected LAI at the hole growth stage of rice. Additionally, the attenuation rate of LAI during CK treatment at the grain-filling stage seemed to be 
significantly higher than those of $\mathrm{ZnO} N P$ s treatments. There was no significant relationship between the attenuation rate of LAI and $\mathrm{ZnO}$ NPs dosage.

Table 4. Leaf area index and attenuation rate of leaf area at grain-filling stage of rice under different ZnO NPs application amounts.

\begin{tabular}{ccccc}
\hline \multirow{2}{*}{ Treatments } & \multicolumn{3}{c}{ Leaf Area Index } & \multirow{2}{*}{$\begin{array}{c}\text { Attenuation Rate of Leaf Area Index } \\
\text { at Grain-Filling Stage (LAI d }\end{array}$} \\
\cline { 2 - 4 } & Jointing & Heading & Maturity & $0.0603 \pm 0.0102^{\mathrm{a}}$ \\
\hline CK & $4.29 \pm 0.10^{\mathrm{c}}$ & $6.57 \pm 0.33^{\mathrm{a}, \mathrm{b}}$ & $3.80 \pm 0.08^{\mathrm{c}}$ & $0.0536 \pm 0.0067^{\mathrm{b}}$ \\
T1 & $4.38 \pm 0.19^{\mathrm{b}, \mathrm{c}}$ & $6.55 \pm 0.25^{\mathrm{a}, \mathrm{b}}$ & $4.09 \pm 0.13^{\mathrm{b}}$ & $0.0522 \pm 0.0076^{\mathrm{b}}$ \\
T2 & $4.42 \pm 0.12^{\mathrm{b}, \mathrm{c}}$ & $6.54 \pm 0.19^{\mathrm{b}}$ & $4.14 \pm 0.07^{\mathrm{b}}$ & $0.0552 \pm 0.0021^{\mathrm{b}}$ \\
T3 & $4.63 \pm 0.23^{\mathrm{a}, \mathrm{b}}$ & $6.82 \pm 0.13^{\mathrm{a}, \mathrm{b}}$ & $4.28 \pm 0.08^{\mathrm{ab}}$ & $0.0520 \pm 0.0062^{\mathrm{b}}$ \\
T4 & $4.86 \pm 0.20^{\mathrm{a}}$ & $6.90 \pm 0.13^{\mathrm{a}, \mathrm{b}}$ & $4.51 \pm 0.16^{\mathrm{a}}$ & $0.0535 \pm 0.0023^{\mathrm{b}}$ \\
T5 & $4.85 \pm 0.15^{\mathrm{a}}$ & $6.97 \pm 0.14^{\mathrm{a}}$ & $4.51 \pm 0.09^{\mathrm{a}}$ &
\end{tabular}

Note: Values within the same column followed by different letters are significantly different at the 0.05 probability level.

\subsection{Photosynthetic Potential}

The data in Table 5 demonstrates that the photosynthetic leaf potential of all treatments increased with the continued growth and development of the rice. In the slowing-jointing, jointing-heading, and heading-maturity stages, the photosynthetic potentials from most of the $\mathrm{ZnO}$ NPs treatments were higher than CK treatment. The results suggest that $\mathrm{ZnO}$ NPs application increased the photosynthetic potential at three key growth stages. Increasing $\mathrm{ZnO}$ NPs dosage showed no significant difference in photosynthetic potential in each $\mathrm{ZnO}$ NPs treatment at three key growth stages.

Table 5. Leaf photosynthetic potential of rice under different ZnO NPs application amounts.

\begin{tabular}{cccc}
\hline \multirow{2}{*}{ Treatments } & \multicolumn{3}{c}{ Photosynthetic Potential $\left(\times \mathbf{1 0}^{\mathbf{4}} \mathbf{~ m}^{\mathbf{2}} \mathbf{d ~ h \mathbf { ~ m } ^ { - \mathbf { 2 } } )}\right.$} \\
\cline { 2 - 4 } & Sowing-Jointing & Jointing-Heading & Heading-Maturity \\
\hline CK & $141.75 \pm 4.28^{\mathrm{a}}$ & $172.11 \pm 3.02^{\mathrm{b}}$ & $270.07 \pm 5.79^{\mathrm{b}}$ \\
T1 & $138.84 \pm 1.63^{\mathrm{a}}$ & $182.38 \pm 2.38^{\mathrm{a}}$ & $271.45 \pm 4.12^{\mathrm{b}}$ \\
T2 & $143.61 \pm 4.43^{\mathrm{a}}$ & $180.80 \pm 4.54^{\mathrm{a}}$ & $274.74 \pm 0.87^{\mathrm{a}, \mathrm{b}}$ \\
T3 & $142.26 \pm 2.41^{\mathrm{a}}$ & $182.87 \pm 3.51^{\mathrm{a}}$ & $281.21 \pm 2.90^{\mathrm{a}}$ \\
T4 & $144.76 \pm 3.65^{\mathrm{a}}$ & $177.91 \pm 3.46^{\mathrm{a}, \mathrm{b}}$ & $274.06 \pm 4.93^{\mathrm{a}, \mathrm{b}}$ \\
T5 & $143.12 \pm 3.93^{\mathrm{a}}$ & $178.35 \pm 6.65^{\mathrm{a}, \mathrm{b}}$ & $273.41 \pm 3.63^{\mathrm{b}}$ \\
\hline
\end{tabular}

Note: Values within the same column followed by different letters are significantly different at the 0.05 probability level.

\subsection{SPAD Value}

To further explain the increase of dry matter accumulation in the later growth stages of rice after $\mathrm{ZnO}$ NPs application, the SPAD values of rice leaves were determined between 1 August to 12 October, at the heading-maturity stage. The results are presented in Figure 1. The leaf SPAD values of $\mathrm{ZnO}$ NPs treatments showed a gradual decrease during the grain-filling period. Compared with SPAD readings during ZnO NPs treatments, the CK treatment data displayed lower SPAD at most measurements. As shown in Figure 1, leaf SPAD values of T3, T4 and T5 remained high even on 12 October, validating the high photosynthetic and dry matter synthesis capacities.

\subsection{Grain Quality of the Rice}

As depicted in Table 6, significant differences expected in brown rice and milled rice rates between CK and ZnO NPs treatments were not present. However, the ZnO NPs treatments showed higher outcomes of the brown milled rice rate, with an average growth rate of $0.88 \%$ and $0.75 \%$ compared with CK treatment data. The brown and milled rice rates increased with increasing amounts of $\mathrm{ZnO}$ NPs applied. No significant effects on head rice rate were observed between $\mathrm{CK}$ and $\mathrm{ZnO}$ NPs treatments. The head rice rate of 
$\mathrm{T} 1$ was significantly higher than $\mathrm{T} 4$ and $\mathrm{T} 5$, suggesting that the head rice rate decreased with increasing ZnO NPs dosage.

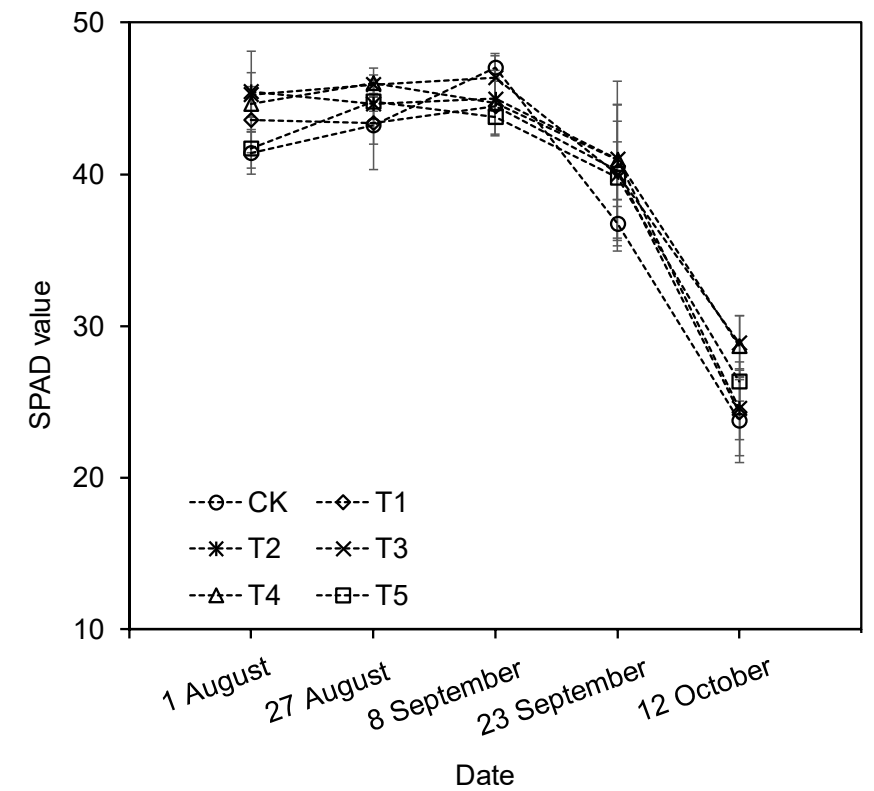

Figure 1. Variation of SPAD value in rice growth period under different ZnO NPs application amounts.

Table 6. Rice quality under different ZnO NPs application amounts.

\begin{tabular}{|c|c|c|c|c|c|c|c|c|}
\hline Treatments & $\begin{array}{c}\text { Brown Rice } \\
\text { Rate (\%) }\end{array}$ & $\begin{array}{c}\text { Milled Rice } \\
\text { Rate (\%) }\end{array}$ & $\begin{array}{c}\text { Head Rice } \\
\text { Rate (\%) }\end{array}$ & $\begin{array}{c}\text { Chalkiness } \\
\text { Size (\%) }\end{array}$ & $\begin{array}{c}\text { Chalkiness } \\
\text { Grain Rate (\%) }\end{array}$ & $\begin{array}{l}\text { Chalkiness } \\
\text { Degree (\%) }\end{array}$ & $\begin{array}{c}\text { Amylose } \\
\text { Content (\%) }\end{array}$ & $\begin{array}{c}\text { Protein } \\
\text { Content }(\%)\end{array}$ \\
\hline CK & $85.07 \pm 0.22^{a}$ & $75.45 \pm 0.22^{a}$ & $64.07 \pm 0.81^{\mathrm{a}, \mathrm{b}}$ & $56.81 \pm 1.23^{a}$ & $15.42 \pm 1.03^{a}$ & $8.76 \pm 0.29^{a}$ & $17.47 \pm 0.40^{\mathrm{a}}$ & $7.20 \pm 0.20^{a}$ \\
\hline $\mathrm{T} 1$ & $85.74 \pm 0.03^{a}$ & $75.67 \pm 0.37^{a}$ & $67.39 \pm 1.73^{a}$ & $54.20 \pm 0.34^{\mathrm{a}}$ & $14.56 \pm 0.98^{\mathrm{a}, \mathrm{b}}$ & $7.89 \pm 0.22^{a, b}$ & $17.63 \pm 0.12^{\mathrm{a}}$ & $7.37 \pm 0.15^{a}$ \\
\hline $\mathrm{T} 2$ & $85.51 \pm 0.06^{a}$ & $76.10 \pm 0.15^{a}$ & $63.31 \pm 0.38^{b}$ & $49.47 \pm 1.92^{\mathrm{a}}$ & $11.01 \pm 0.96^{\mathrm{b}}$ & $5.45 \pm 0.14^{\mathrm{b}}$ & $17.62 \pm 0.10^{\mathrm{a}}$ & $7.47 \pm 0.15^{a}$ \\
\hline T3 & $85.84 \pm 0.08^{a}$ & $76.22 \pm 0.21^{a}$ & $65.85 \pm 0.29^{a, b}$ & $47.63 \pm 3.00^{\mathrm{a}}$ & $10.71 \pm 1.08^{b}$ & $5.10 \pm 0.22^{b}$ & $17.70 \pm 0.06^{\mathrm{a}}$ & $7.47 \pm 0.15^{a}$ \\
\hline $\mathrm{T} 4$ & $85.94 \pm 0.33^{a}$ & $76.11 \pm 0.33^{a}$ & $62.86 \pm 0.18^{b}$ & $53.27 \pm 0.90^{\mathrm{a}}$ & $13.73 \pm 0.32^{\mathrm{a}, \mathrm{b}}$ & $7.31 \pm 0.21^{\mathrm{a}, \mathrm{b}}$ & $17.93 \pm 0.10^{\mathrm{a}}$ & $7.63 \pm 0.31^{a}$ \\
\hline $\mathrm{T} 5$ & $86.06 \pm 0.13^{a}$ & $75.85 \pm 0.25^{a}$ & $63.71 \pm 0.23^{b}$ & $49.53 \pm 4.91^{\mathrm{a}}$ & $11.97 \pm 1.04^{b}$ & $5.93 \pm 0.19^{b}$ & $17.63 \pm 0.25^{a}$ & $7.40 \pm 0.15^{a}$ \\
\hline
\end{tabular}

Note: Values within the same column followed by different letters are significantly different at the 0.05 probability level.

Analysing rice appearance quality, chalkiness size, chalkiness grain rate, and chalkiness degree yielded better results for CK than the ZnO NPs treatments. However, overall there was no apparent difference in chalkiness size. With increasing ZnO NPs dosage, the chalkiness size, chalkiness grain rate and chalkiness degree showed no noticeable trend. The rice appearance quality results imply that ZnO NPs application would slightly enhance the appearance quality of rice.

The nutritional quality of rice, amylose content and protein content of CK was lower than those of the ZnO NPs treatment groups, with no apparent differences. With increasing $\mathrm{ZnO}$ NPs dosage, the amylose content, and the protein content first increased and then decreased. The highest amylose content was $17.93 \%$, and the protein content of T4 was $7.63 \%$.

\subsection{Zn Content of Rice Grain}

As presented in Table 7, the applied ZnO NPs significantly augmented the Zn content in rice grain. Compared with the CK, the applied ZnO NPs of the basal stage increased the $\mathrm{Zn}$ content in rice grain by $20.46-41.09 \%$. The $\mathrm{Zn}$ content of rice grain increased with the $\mathrm{ZnO}$ NPs dosage increase. Similarly, the applied ZnO NPs improved the Zn content in brown rice and glume. The $\mathrm{Zn}$ content was significantly more increased in glume compared to brown rice. The basal stage applied ZnO NPs increased the Zn content by $25.78-48.29 \%$ in brown rice and $36.48-66.50 \%$ in glume. The $\mathrm{Zn}$ content increasing of brown rice was remarkably lower than the vegetative organs, indicating that more $\mathrm{Zn}$ was sediment in the 
vegetative organs and not efficiently positioned in rice grains. The typical opposite pattern was observed in the polished rice and aleurone layer after further processing of brown rice. The applied ZnO NPs augmented the Zn content by $16.67-35.35 \%$ and $3.94-26.33 \%$ for the edible polished rice and inedible aleurone layer. Such an outcome may be because $\mathrm{ZnO}$ NPs improved the relocation of $\mathrm{Zn}$ from the aleurone layer to polished rice, implying that $\mathrm{ZnO}$ NPs could provide better nutrition for the body of humans.

Table 7. Zinc concentration of rice grain, glume and brown rice under different ZnO NPs application amounts.

\begin{tabular}{|c|c|c|c|c|c|}
\hline Treatments & $\begin{array}{c}\text { Rice Grain } \\
\left(\mathrm{mg} \mathrm{kg}^{-1}\right)\end{array}$ & $\begin{array}{c}\text { Glume } \\
\left(\mathrm{mg} \mathrm{kg}^{-1}\right)\end{array}$ & $\begin{array}{l}\text { Brown Rice } \\
\left(\mathrm{mg} \mathrm{kg}^{-1}\right)\end{array}$ & $\begin{array}{l}\text { Polished Rice } \\
\left(\mathrm{mg} \mathrm{kg}^{-1}\right)\end{array}$ & $\begin{array}{l}\text { Aleurone Layer } \\
\left(\mathrm{mg} \mathrm{kg}^{-1}\right)\end{array}$ \\
\hline CK & $16.86 \pm 0.40^{f}$ & $34.25 \pm 0.80^{c}$ & $13.81 \pm 0.45^{\mathrm{d}}$ & $11.39 \pm 0.49^{\mathrm{d}}$ & $32.81 \pm 1.07^{\mathrm{f}}$ \\
\hline $\mathrm{T} 1$ & $19.67 \pm 0.08^{\mathrm{e}}$ & $33.52 \pm 1.16^{\mathrm{c}}$ & $17.37 \pm 0.17^{\mathrm{c}}$ & $13.72 \pm 0.12^{\mathrm{c}}$ & $44.78 \pm 0.24^{\mathrm{e}}$ \\
\hline $\mathrm{T} 2$ & $20.95 \pm 0.07^{\mathrm{d}}$ & $41.01 \pm 1.52^{\mathrm{a}}$ & $17.55 \pm 0.31^{\mathrm{c}}$ & $13.90 \pm 0.23^{c}$ & $47.07 \pm 0.96^{\mathrm{d}}$ \\
\hline $\mathrm{T} 3$ & $21.79 \pm 0.05^{c}$ & $38.24 \pm 2.32^{a, b}$ & $19.07 \pm 0.34^{b}$ & $15.33 \pm 0.29^{b}$ & $48.75 \pm 0.39^{c}$ \\
\hline $\mathrm{T} 4$ & $22.47 \pm 0.05^{\mathrm{b}}$ & $34.67 \pm 3.02^{b, c}$ & $20.48 \pm 0.50^{a}$ & $16.07 \pm 0.65^{\mathrm{a}}$ & $54.63 \pm 0.90^{\mathrm{a}}$ \\
\hline $\mathrm{T} 5$ & $22.82 \pm 0.12^{\mathrm{a}}$ & $40.74 \pm 2.13^{\mathrm{a}}$ & $19.92 \pm 0.45^{\mathrm{a}}$ & $15.79 \pm 0.36^{\mathrm{a}, \mathrm{b}}$ & $50.53 \pm 1.03^{b}$ \\
\hline
\end{tabular}

Note: Values within the same column followed by different letters are significantly different at the 0.05 probability level.

\section{Discussion}

Our results found that as a new type of zinc fertiliser $\mathrm{ZnO}$ NPs increased rice yield by $2.5 \%$ to $11.8 \%$ compared with CK treatment. It is worth noting that the available zinc content of the tested soil in this study was $0.98 \mathrm{mg} \mathrm{kg}^{-1}$. According to Liu's [29] zinc fertiliser application classification to soil and crops, the tested soil belongs to the effective area of zinc fertiliser $\left(0.5-1.0 \mathrm{mg} \mathrm{kg}^{-1}\right)$. Supplementing zinc fertiliser on zinc-deficient soils can increase crop yields. ZnO NPs application improved the efficient quantities of rice panicles and rice spikelets for each of the panicles. Therefore, the increased spikelet number of rice crops made the full-grain rate and 1000-grain weight stable. The results in the current study indicate that more dry substances could be collected if $\mathrm{ZnO}$ NPs were applied at the jointing, heading and mature stages, suggesting that ZnO NPs would facilitate final yield increases. Notably, zinc is an essential component of hundreds of plant enzymes that participate in chlorophyll and auxin synthesis and the synthesis and transformation of carbohydrates. Increased levels of zinc in rice will promote photosynthesis and photosynthetic efficiency. Many scholars believe that the high production of photosynthetic substances is essential to achieving a high grain yield [30,31]. In this study, the application of $\mathrm{ZnO} N$ Ps significantly increased the grain zinc content. Higher zinc content resulted in higher photosynthetic potential and more photosynthetic substances. Additionally, applied $\mathrm{ZnO}$ NPs had significantly increased the LAI of rice during the whole growth period. They decreased the attenuation rate of LAI at the grain-filling stage, suggesting more photosynthetic substances transferred to grains from leaves. Such mechanisms directly contribute to the outcomes of $\mathrm{ZnO}$ NPs to yield formation. The highest grain yield was achieved when $\mathrm{ZnO} N P s$ application level was $2.4 \mathrm{~g} \mathrm{Zn} \mathrm{pot}^{-1}\left(60 \mathrm{~kg} \mathrm{hm}^{-2}\right)$. At this $\mathrm{ZnO}$ NPs application amount, the yield of $\mathrm{T} 4$ was $7.55 \%$ higher than that of treatment without ZnO NPs.

Additionally, the rice quality is influenced by ZnO NPs application. Zinc can activate flavour enzymes, decomposing sugar, fat, and protein in rice. Flavour substances such as fatty acids, aldehydes, and ketones are increased, and the overall taste of rice is improved [32,33]. The data in our study showed that the appropriate amount of basal application of $\mathrm{ZnO}$ NPs increased the rate of the brown rice, milled rice and head rice, improving the rice processing quality. In addition, the chalkiness size, chalkiness grain rate, chalkiness degree, amylose content and protein content were also enhanced by $\mathrm{ZnO}$ NPs application. Such outcomes may be related to the high leaf area index, photosynthetic potential, dry matter accumulation, and low decreasing rate of leaf area at the grain-filling stage. Studies have also proved that zinc fertilisers can promote the transfer of photosynthetic products to the grains and increase the activity of rice protein synthase $[18,22,23]$. 
For $\mathrm{Zn}$ nutrition in rice grain, $\mathrm{ZnO}$ NPs application primarily increased the $\mathrm{Zn}$ content of edible polished rice, which also promoted the relocation of $\mathrm{Zn}$ from the aleurone layer [34]. More $\mathrm{Zn}$ nutritious supplications for the human body are of great significance while also further increasing the nutritional value of rice.

The effectiveness of zinc in ZnO NPs has been suggested as one primary mechanism of nanomaterial affecting plant growth. As the size of the nanoparticles is relatively tiny, $\mathrm{ZnO}$ NPs could not adhere to the soil particle that would result in loss of the $\mathrm{Zn}$ ingredients [35,36]. Moreover, $\mathrm{ZnO}$ NPs, which can slowly and continuously release $\mathrm{Zn}[37,38]$, effectively delivering a continuous supply of $\mathrm{Zn}$ to meet the need of the plants [35,39]. Sufficient $\mathrm{Zn}$ was adsorbed by rice roots during the growth period, promoting the growth and development of the rice, especially at the heading-mature stage. Additionally, $\mathrm{ZnO}$ NPs with potent free radicals possess augmented chemical activity and react with soil organic substances, promoting the decomposition of organic substances and the release of soil nutrients [40]. For example, $\mathrm{Zn}$ ions released from $\mathrm{ZnO}$ NPs form $\mathrm{Zn}$ phosphate agglomerates and promote nutrient elements to be more easily absorbed and utilised by the root system, meeting the needs of rice growth [41]. Many studies have shown that nanomaterials can significantly increase the nutrient content of available nitrogen, phosphorus, and potassium in the soil by affecting the activities of related microorganisms [18,40]. Notably, ZnO NPs in rice plants could directly increase the peroxidase activity and help remove the active oxygen, improving the resistance of rice effectively [42]. Moreover, $\mathrm{ZnO}$ NPs enhanced chlorophyll synthesis in leaves by affecting the activities of glutamyl-tRNA reductase and protoporphyrinogen oxidase [43]. This may explain the observed high SPAD values, photosynthesis and photosynthetic efficiency during the grain-filling period in $\mathrm{ZnO}$ NPs treatments, leading to higher grain yields and better rice qualities of ZnO NPs treatments than those without $\mathrm{ZnO}$ NPs.

\section{Conclusions}

The current study clearly demonstrates that ZnO NPs improve the rice yield, rice quality, and Zn content of the grain. Applied ZnO NPs at the basal stage can increase grain yield and yield components. Moreover, the grain yield firstly increased and then decreased with increasing amounts of $\mathrm{ZnO} N$ Ps application. The higher grain yields of ZnO NPs treatment resulted in higher panicle number, spikelets per panicle, 1000-grain weight, and filled grain rate. In addition, $\mathrm{ZnO}$ NPs application improved the dry matter accumulation, leaf area index, SPAD value, and photosynthetic potential in the whole rice growth period. In the current study, ZnO NPs application exhibited favourable benefits in rice processing, appearance, and nutritional value. ZnO NPs application significantly increased the Zn content of edible polished rice and promoted the relocation of $\mathrm{Zn}$ from the aleurone layer, further increasing the nutritional value of rice. Therefore, $\mathrm{ZnO}$ NPs were shown to be promising nanomaterials as a micronutrient fertiliser, enabling growth promotion for rice to obtain better yields and enhanced nutritional quality.

Author Contributions: The contributions of H.Z. (Haipeng Zhang), R.W., Y.Y. and H.Z. (Hongcheng Zhang) involved in designing the manuscript; H.Z. (Haipeng Zhang), R.W., Z.C., P.C. and H.L. carried out this experiment; H.Z. (Haipeng Zhang), R.W., P.C., Y.Y. and H.Z. (Hongcheng Zhang) analyzed the data and wrote the manuscript; H.Z. (Haipeng Zhang), Y.Y. and H.Z. (Hongcheng Zhang) acquired funding. All authors have read and agreed to the published version of the manuscript.

Funding: This research was funded by National Nature Science Foundation of China (31901447, 41701329), National Key Research Program of China (2016YFD0300503), Earmarked Found for Jiangsu Agriculture Industry Technology System (JATS [2019]444), Key R\&D Plan Program of Jiangsu Province (BE2020319), Innovation and Entrepreneurship Program of Jiangsu Province (JSSCBS20211062) and the project by the Priority Academic Program Development of Jiangsu Higher Education Institutions.

Institutional Review Board Statement: Not applicable.

Informed Consent Statement: Not applicable. 


\section{Data Availability Statement: Not applicable.}

Conflicts of Interest: The authors declare no conflict of interest.

\section{References}

1. Cakmak, I. Enrichment of cereal grains with zinc: Agronomic or genetic biofortification? Plant Soil 2008, 302, 1-17. [CrossRef]

2. Gibson, R.S. Zinc: The missing link in combating micronutrient malnutrition in developing countries. Proc. Nutr. Soc. 2006, 65, 51-60. [PubMed]

3. Hotz, C. Dietary indicators for assessing the adequacy of population zinc intakes. Food Nutr. Bull. 2007, 28, 430-453.

4. Yang, X.E.; Chen, W.R.; Feng, Y. Improving human micronutrient nutrition through biofortification in the soil-plant system: China as a case study. Environ. Geochem. Health 2007, 29, 413-428. [CrossRef]

5. White, P.J.; Broadley, M.R. Biofortifying crops with essential mineral elements. Trends Plant Sci. 2005, 10, 586-593. [CrossRef] [PubMed]

6. Frossard, E.; Bucher, M.; Mahler, F.; Mozafar, A.; Hurrell, R.F. Potential for increasing the content and bioavailability of Fe, Zn and Ca in plants for human nutrition. J. Sci. Food Agric. 2000, 80, 861-879.

7. Yan, S.; Wu, F.; Zhou, S.; Yang, J.; Tang, X.; Ye, W. Zinc oxide nanoparticles alleviate the arsenic toxicity and decrease the accumulation of arsenic in rice (Oryza sativa L.). BMC Plant Biol. 2021, 21, 150.

8. Phattarakul, N.; Rerkasem, B.; Li, L.J.; Wu, L.H.; Zou, C.Q.; Ram, H.; Sohu, V.S.; Kang, B.S.; Surek, H.; Kalayci, M.; et al. Biofortification of rice grain with zinc through zinc fertilization in different countries. Plant Soil 2012, 361, $131-141$.

9. Cakmak, I.; Kalayci, M.; Kaya, Y.; Torun, A.A.; Aydin, N.; Wang, Y.; Arisoy, Z.; Erdem, H.; Gokmen, O.; Ozturk, L.; et al. Biofortification and localization of zinc in wheat grain. J. Agric. Food Chem. 2010, 58, 9092-9102. [PubMed]

10. Zeng, Y.W.; Wang, L.X.; Du, J.; Wang, S.M.; Yang, Y.C.; Li, Q.W.; Sun, Z.H.; Pu, X.Y.; Du, W. Correlation of mineral elements between milled and brown rice and soils in Yunnan studied by ICP-AES. Spectrosc. Spect. Anal. 2009, 29, $1413-1417$.

11. Hussain, A.; Ali, S.; Rizwan, M.; Rehman, M.Z.U.; Javed, M.R.; Imran, M.; Chatha, S.A.; Nazir, R. Zinc oxide nanoparticles alter the wheat physiological response and reduce the cadmium uptake by plants. Environ. Pollut. 2018, 242, 1518-1526. [CrossRef] [PubMed]

12. Rizwan, M.; Ali, S.; Ali, B.; Adrees, M.; Arshad, M.; Hussain, A.; Rahman, M.Z.U.; Waris, A.A. Zinc and iron oxide nanoparticles improved the plant growth and reduced the oxidative stress and cadmium concentration in wheat. Chemosphere 2019, 214, 269-277. [CrossRef] [PubMed]

13. Rizwan, M.; Ali, S.; Rehman, M.Z.U.; Adrees, M.; Arshad, M.; Qayyum, M.F.; Ali, L.; Hussain, A.; Chatha, S.A.S.; Imran, M. Alleviation of cadmium accumulation in maize (Zea mays L.) by foliar spray of zinc oxide nanoparticles and biochar to contaminated soil. Environ. Pollut. 2019, 248, 358-367. [CrossRef] [PubMed]

14. Fang, Y.; Wang, L.; Xin, Z.H.; Zhao, L.Y.; An, X.X.; Hu, Q.H. Effect of foliar application of zinc, selenium, and iron fertilizers on nutrients concentration and yield of rice grain in China. J. Agric. Food Chem. 2008, 56, 2079-2084. [CrossRef]

15. Prakash, P.; Hemalatha, M.; Joseph, M. Zinc accounting for lowland rice (Oryza sativa L.) under different methods of zinc application with green leaf manuring. Adv. Crop Sci. Tech. 2018, 6, 1000374.

16. Wu, F.; Fang, Q.; Yan, S.W.; Pan, L.; Tang, X.J.; Ye, W.L. Effects of zinc oxide nanoparticles on arsenic stress in rice (Oryza sativa L.): Germination, early growth, and arsenic uptake. Environ. Sci. Pollut. Res. 2020, 27, 26974-26981. [CrossRef]

17. Naik, S.K.; Das, D.K. Relative performance of chelated zinc and zinc sulphate for lowland rice (Oryza sativa L.). Nutr. Cycl. Agroecosyst. 2008, 81, 219-227. [CrossRef]

18. Yang, G.Y.; Yuan, H.Y.; Ji, H.T.; Liu, H.J.; Zhang, Y.F.; Wang, G.D.; Chen, L.G.; Guo, Z. Effect of ZnO nanoparticles on the productivity, Zn biofortification, and nutritional quality of rice in a life cycle study. Plant Physiol. Bioch. 2021, 163, 87-94. [CrossRef]

19. Elemike, E.E.; Uzoh, I.M.; Onwudiwe, D.C.; Babalola, O.O. The role of nanotechnology in the fortification of plant nutrients and improvement of crop production. Appl. Sci. 2019, 9, 499. [CrossRef]

20. Lowry, G.V.; Avellan, A.; Gilbertson, L.M. Opportunities and challenges for nanotechnology in the agri-tech revolution. Nat. Nanotechnol. 2019, 14, 517-522. [CrossRef] [PubMed]

21. Kah, M.; Tufenkji, N.; White, J.C. Nano-enabled strategies to enhance crop nutrition and protection. Nat. Nanotechnol. 2019, 14, 532-540. [CrossRef] [PubMed]

22. Dimkpa, C.O.; Andrews, J.; Fugice, J.; Singh, U.; Bindraban, P.S.; Elmer, W.H.; Gardea-Torresdey, J.L.; White, J.C. Facile coating of urea with low-dose $\mathrm{ZnO}$ nanoparticles promotes wheat performance and enhances Zn uptake under drought stress. Front. Plant Sci. 2020, 11, 168. [CrossRef]

23. Subbaiah, L.V.; Prasad, T.N.V.K.V.; Krishna, T.G.; Sudhakar, P.; Reddy, P.R.; Pradeep, T. Novel effects of nanoparticulate delivery of zinc on growth, productivity, and zinc biofortification in maize (Zea mays L.). J. Agric. Food Chem. 2016, 64, 3778-3788. [CrossRef] [PubMed]

24. Dimkpa, C.O.; White, J.C.; Elmer, W.H.; Gardea-Torresdy, J. Nanoparticle and ionic Zn promote nutrient loading of sorghum grain under low NPK fertilization. J. Agric. Food Chem. 2017, 65, 8552-8559. [CrossRef]

25. Ali, S.; Rizwan, M.; Noureen, S.; Anwar, S.; Ali, B.; Naveed, M.; Allah, E.F.A.; Alqarawi, A.A.; Ahamad, P. Combined use of biochar and zinc oxide nanoparticle foliar spray improved the plant growth and decreased the cadmium accumulation in rice (Oryza sativa L.) plant. Environ. Sci. Pollut. Res. 2019, 26, 11288-11299. [CrossRef] [PubMed] 
26. Dimkpa, C.O.; Singh, U.; Bindraban, P.S.; Adisa, I.O.; Elmer, W.H.; Gardea-Torresdey, J.L.; White, J.C. Addition-omission of zinc, copper, and boron nano and bulk oxide particles demonstrate element and size-specific response of soybean to micronutrients exposure. Sci. Total Environ. 2019, 665, 606-616. [CrossRef] [PubMed]

27. Singh, D.; Kumar, A. Quantification of metal uptake in Spinacia oleracea irrigated with water containing a mixture of $\mathrm{CuO}$ and ZnO nanoparticles. Chemosphere 2020, 243, 125239. [CrossRef] [PubMed]

28. Hu, Y.J.; Cong, S.M.; Zhang, H.C. Comparison of the grain quality and starch physicochemical properties between Japonica rice cultivars with different contents of amylose, as affected by nitrogen fertilization. Agriculture 2021, 11, 616. [CrossRef]

29. Liu, Z. Regularities of content and distribution of zinc in soils of China. Sci. Agric. Sin. 1994, 27, 30-37.

30. Dou, Z.; Li, Y.Y.; Guo, H.L.; Chen, L.R.; Jiang, J.L.; Zhou, Y.C.; Xu, Q.; Xing, Z.P.; Gao, H.; Zhang, H.C. Effects of mechanically transplanting methods and planting densities on yield and quality of Nanjing 2728 under rice-crayfish continuous production system. Agronomy 2021, 11, 488. [CrossRef]

31. Zhang, H.C.; Gong, J.L. Research status and development discussion on high-yield agronomy of mechanized planting rice in China. Sci. Agric. Sin. 2014, 47, 1273-1289.

32. Kheyri, N.; Norouzi, H.A.; Mobasser, H.R.; Torabi, B. Effect of silicon and zinc nanoparticles on growth, yield, and biochemical characteristics of rice. Agron. J. 2019, 111, 3084-3090. [CrossRef]

33. Tyagi, R.; Sharma, A.; Srivastava, P.C.; Shankhdhar, D.; Shankhdhar, S.C. Modulation of phytic acid and phytic acid-zinc molar ratio by different modes of zinc application in rice. Indian J. Plant Physiol. 2018, 23, 529-535. [CrossRef]

34. Yin, H.J.; Guo, X.P.; Stomph, T.; Li, L.J.; Zhang, F.S.; Zou, C.Q. Zinc concentration in rice (Oryza sativa L.) grains and allocation in plants as affected by different zinc fertilization strategies. Commun. Soil Sci. Plan. 2016, 47, 761-768. [CrossRef]

35. Zhang, T.; Sun, H.D.; Lv, Z.Y.; Cui, L.L.; Mao, H.; Kopittke, P.M. Using synchrotron-based approaches to examine the foliar application of $\mathrm{ZnSO}_{4}$ and $\mathrm{ZnO}$ nanoparticles for field-growth winter wheat. J. Agric. Food Chem. 2018, 66, 2572-2579. [CrossRef]

36. Rui, M.M.; Ma, C.X.; Hao, Y.; Guo, J.; Rui, Y.K.; Tang, X.L.; Zhao, Q.; Fan, X.; Zhang, Z.T.; Hou, T.Q.; et al. Iron oxide nanoparticles as a potential iron fertilizer for peanut (Arachis hypogaea). Front. Plant Sci. 2016, 7, 815. [CrossRef] [PubMed]

37. Samart, S.; Chutipaijit, S. Growth of pigmented rice (Oryza sativa L. cv. Riceberry) exposed to ZnO nanoparticles. Mater. Today Proc. 2019, 17, 1987-1997. [CrossRef]

38. Kopittke, P.M.; Lombi, E.; Wang, P.; Schjoerring, J.K.; Husted, S. Nanomaterials as fertilizers for improving plant mineral nutrition and environmental outcomes. Environ. Sci. Nano 2019, 6, 3513. [CrossRef]

39. Sun, H.D.; Du, W.; Peng, Q.Q.; Lv, Z.Y.; Mao, H.; Kopittke, P.M. Development of ZnO nanoparticles as an efficient Zn fertilizer: Using synchrotron-based techniques and laser ablation to examine elemental distribution in wheat grain. J. Agric. Food Chem. 2020, 68, 5068-5075. [CrossRef]

40. Garcia-Gomez, C.; Obrador, A.; Gonzalez, D.; Babin, M.; Fernandez, M.D. Comparative effect of ZnO NPs, ZnO bulk and ZnSO 4 in the antioxidant defences of two plant species growing in two agricultural soils under greenhouse conditions. Sci. Total Environ. 2017, 589, 11-24. [CrossRef] [PubMed]

41. Josko, I.; Oleszczuk, P.; Futa, B. The effect of inorganic nanoparticles $\left(\mathrm{ZnO}, \mathrm{Cr}_{2} \mathrm{O}_{3}, \mathrm{CuO}\right.$ and $\left.\mathrm{Ni}\right)$ and their bulk counterparts on enzyme activities in different soils. Geoderma 2014, 232-234, 528-537. [CrossRef]

42. Wang, X.P.; Li, Q.Q.; Pei, Z.M.; Wang, S.C. Effects of zinc oxide nanoparticle on the growth, photosynthetic traits, and antioxidative enzymes in tomato plants. Biol. Plant. 2018, 62, 801-808. [CrossRef]

43. Siddiqui, Z.A.; Parveen, A.; Ahmad, L.; Hashem, A. Effects of graphene oxide and zinc oxide nanoparticles on growth, chlorophyll, carotenoids, proline contents and diseases of carrot. Sci. Hortic. 2019, 249, 374-382. [CrossRef] 